In man, also, mycoplasmas occur in the respiratory and genital tracts. However, Mycoplasma pneumoniae, which causes cold-agglutinin-positive primary atypical pneumonia, ${ }^{2-4}$ is the only one of undisputed pathogenicity. As in animals, several apparently harmless species inhabit the human upper respiratory tract, though one of them has recently been shown to produce exudative pharyngitis in volunteers." Two of the strains which occur in the human oropharynx are also common contaminants of tissue cultures.

The role of mycoplasmas in genital disease is less clear-cut than that of $M$. pneumoniae in primary atypical pneumonia. In particular the importance of mycoplasmas in non-gonococcal urethritis is controversial. But the evidence suggests that the strain commonly found in the human genital tract, $M$. hominis type $\mathrm{I}$, is a potential pathogen and can be a primary cause of septic pelvic infections, such as salpingooophoritis. It can also act as an opportunist, "cashing in" on such primary infections as syphilis, gonorrhoea, and trichomoniasis.

Until the discovery of $M$. pneumoniae, no attempt was made to prepare vaccines for human use, although vaccination of cattle against contagious pleuropneumonia had long been practised. Now preliminary experiments with an inactivated $M$. pneumoniae vaccine ${ }^{6}$ have given encouraging results in human volunteers, though its protective value has still to be evaluated in field trials.

- Recent reports of the isolation of mycoplasmas from tissues of patients with leukaemia, various solid tumours, lupus erythematosus, Reiter's disease, and rheumatoid arthritis ${ }^{7-10}$ have led to speculation on their role in diseases of unknown aetiology. Nevertheless, it is impossible to draw any valid conclusions at present. Though most of these mycoplasmas were isolated after passage through tissue cultures (which are notoriously prone to contamination by them) it seems unlikely that they can all be written off as contaminants. On the other hand, their presence in diseased tissue may not necessarily mean that they cause the disease. A clearer understanding of the role of these isolates may emerge when they have been identified by comparison with one another and with recognized species. Moreover, mycoplasma-like forms which have not so far been cultivated have been observed by electron-microscopy in material from patients with leukaemia. ${ }^{1112}$ Such fastidious parasites might well be of greater importance than the mycoplasmas already isolated. The recent demonstration that mycoplasma infection produces chromosome changes in tissue cultures ${ }^{1314}$ is also of interest in connexion with malignant disease.

\footnotetext{
${ }^{1}$ Klieneberger-Nobel, E., Pleuropneumonia-like Organisms (PPLO) Mycoplasmataceae, 1962. Academic Press, London.

${ }^{2}$ Cook, M. K., Chanock, R. M., Fox, H. H., Huebner, R. J., Buescher E. L., and Johnson, R. T., Brit. med. F., 1960, 1, 905.

${ }^{3}$ Goodburn, G. M., Marmion, B. P., and Kendell, E. J. C., ibid., 1963, 1, 1266.

- Jansson, E., Wager, O., Stenstrom, R., Klemola, E., and Forssell, P., ibid., $1964,1,142$.

${ }_{5}^{5}$ Mufson, M. A., Ludwig, W. M., Purcell, R. H., Cate, T. R., TaylorRobinson, D., and Chanock, R. M., F. Amer. med. Ass., 1965, 192, 1146.

- Jensen, K. E., Senterfit, L. B., Chanock, R. M., Smith, C. B., and Purcell, R. H., ibid, 1965, 194, 248.

' Fallon, R. J., Grist, N. R., Inman, D. R., Lemcke, R. M., Negroni, G., and Woods, D. A., Brit. med. $\mathcal{F}_{\text {., }} 1965, \mathbf{2}, 388$.

* Girardi, A. J., Hayflick, L., Lewis, A. M., and Somerson, N. L., Nature (Lond.), 1965, 205, 188.

${ }^{9}$ Hayflick, L., and Koprowski, H., ibid., 1965, 205, 713.

10 Bartholomew, L. E., Arthr. and Rheum., 1965, 8, 376.

11 Murphy, W. H., Furtado, D., and Plata, E., F. Amer. med. Ass., 1965, $191,110$.

${ }^{12}$ Dmochowski, L., Grey, C. E., Dreyer, D. A., Sykes, J. A., Langford, P. L., and Taylor, H. G., Med. Rec. and Ann., 1964, 57, 563 .

${ }^{13}$ Paton, G. R., Jacobs, J. P., and Perkins, F. T., Nature (Lond.), 1965, $207,43$.

14 Fogh, J., and Fogh, H., Proc. Soc. exp. Biol. (N.Y.), 1965, 119, 233.
}

The occurrence of cold haemagglutinins in $M$. pneumoniae infections raises another question-Does similar " autoantibody" in other disease conditions result from unsuspected mycoplasma infections? Although we do not yet know what stimulus is responsible for the production of cold agglutinins in $M$. pneumoniae infections, this question is at least worth considering.

The study of these small organisms has developed into a pursuit no less exciting and tantalizing than the proverbial quest to find the end of the rainbow. It remains to be seen whether a crock of gold lies at the end of it.

\section{Migraine in Children}

Some doctors consider migraine to be rare before adult life. Others believe it to be commoner in children than in adults, and in one study it was diagnosed in nearly $5 \%$ of all children aged 10-12 years, though less commonly before that age." One reason why migraine in childhood may be misdiagnosed is because the expected classical picture of the disorder is often incomplete in the early years.

In addition to the prime essential for diagnosisparoxysmal headache-at least two of the following four criteria are necessary ${ }^{3}$ : one-sided pain in the head, nausea, visual aura, and a history of migrainous headache in parents or siblings. The attacks are often shorter in children than in adults, and they may be abortive (mild and not necessarily unilateral headaches), while nausea and vomiting are commoner. A transient symptom during the headache phase may be photophobia, or even double vision. A much rarer but remarkable one is the "Alice in Wonderland Syndrome,": in which the child has hallucinations that the size or shape of his body is distorted (Lewis Carroll himself suffered from migraine). During an attack of migraine the patient's face may be pale, or red though cold. Fever may occur, and so may abdominal pain, either during an attack or as a substitute for it (" migraine equivalent").

The word migraine is derived from "hemicrania"; but " half a head" obviously describes only one item in what is a widespread disturbance. Nor does it indicate the underlying disorder, even though the vascular mechanism causing the signs and symptoms is understood. As to the cause of it, three factors which have been widely (and often uncritically) accepted are allergy, epilepsy, and endocrine disturbances. For none of these is the evidence either consistent or corvincing. Not only children with migraine, but also their parents, tend to be more anxious, tense, and sensitive than usual. $^{3}$ Similar observations have been made on children with the periodic syndrome, in which migraine can reasonably be placed as part of a spectrum of disorder, ${ }^{, 5}$ with symptoms which reflect a familial pattern of reaction to stress. $^{6}$

When children with migraine grow up, what happens to them ? A recent paper ${ }^{7}$ describes a follow-up study after an interval of 9 to 14 years from the original diagnosis. Of 81 cases only 58 were traced. About $30 \%$ of these were

1 Burke, E. C., and Peters, G. A., Amer. f. Dis. Child., 1956, 92, 330. Bille, B., Acta paediat. (Uppsala), 1962, 51, Suppl. No. 136.

Vahlquist, B., Int. Arch. Allergy, 1955, 7, 348.

Todd, J., Canad. med. Ass. F., 1955, 73,701.

Apley, J., and Mac Keith, R., The Child and His Symptoms, 1962. Oxford.

- Proc. roy. Soc. Med., 1958, 51, 1023

' Hinrichs, W. L., and Keith, H. M., Mayo Clin. Proc., 1965, 40, 593. 
completely free from headaches, nearly $50 \%$ were considerably improved, and $20 \%$ were no better. The study suffers from the defect that it was conducted by questionaries answered (or, too often, not answered) by the parents. The true rate of recovery or improvement is probably considerably lower, and in any event it is important to know not simply whether headaches cease but whether they are replaced by other symptoms.

How effective is treatment in helping children to grow out of migraine ? The effects of treatment on the prognosis have not been investigated thoroughly, perhaps because the causes are not agreed (and may be many) and because most treatment is aimed not at underlying causes and prevention but at relieving attacks. In children the attacks are often relieved by aspirin, though ergotamine preparations may be needed if they are severe. In the prevention of attacks a comprehensive approach is likely to give the best long-term results. Attention should be paid to all the possible "triggers," physical and emotional, and neither diagnosis nor management can be complete without considering the whole child in the context of the family. ${ }^{5}$

\section{Anne Mowbray's Teeth}

It could be argued that human teeth stand high on the list of potential victims of evolutionary attack, that sooner or later they are destined for elimination. We have already shed two premolars several million years ago, when we were no more than an unfulfilled promise among the archaic primates. We munched our way through most of the Old Stone Age with twelve molar teeth, but, safely out of it, began to suppress our wisdoms. As twilight falls on the House of Plantagenet we find that of the "Princes in the Tower" (if such they are) Edward had failed to develop his distal maxillary premolars, and Richard suppressed a second milk molar. Now it appears that their contemporary and collateral, Anne Mowbray, had congenital absence of both left second molars. ${ }^{1}$

This is a rare anomaly and may be considered as dental one-upmanship over the ancient Scythian king who merely suffered from a deep impaction of this tooth. By to-day, with the march of genes and generations, congenital absence of every tooth has been recorded.

Anne Mowbray, born in 1472, died in 1481 just before her ninth birthday. She had four carious milk teeth in her jaws and two permanent molars already with multiple cavities-a caries rate of $23 \%$ in her erupted teeth. How does this compare with other children, or adults, of her time ? Unfortunately this question cannot easily be answered. It is perhaps paradoxical that we know less about dental disease in the fifteenth century than in Anglo-Saxon or prehistoric times. There are two reasons for this: first, the more ancient the material is, the more investigation it is likely to attract ; secondly, burials later than pagan are still mostly lying inaccessible in churchyards that are still in use. But certainly dental caries has tended to increase appreciably during the past five millennia. H. Brabant and A. Sahly ${ }^{2}$ in an examination of nearly 12,000 teeth from Neolithic to Iron Age times in France and Belgium found caries

Rushton, M. A., Brit. dent. F., 1965, 119, 355.

Brabant, H., and Sahly, A., Acta Stomatol. belg, 1964, 59, 285.

3 Brit. med. f., 1965, 2, 1197. frequencies of $2.5-8.0 \%$, the disease showing itself almost entirely in adults. A recent survey of Norwich teeth from Tudor and later burials showed that about $25 \%$ of all teeth had been lost before death, while $18 \%$ of the surviving teeth were carious. In this investigation the children were found to have $16 \%$ of their milk teeth carious, and the first and second permanent molars often showed cavitation, usually interstitial or occlusal, within a year or two of eruption. The gradual rise in the decay and loss of teeth continues through to the twentieth century, and it is difficult to avoid the conclusion that dietary factors largely contribute to it. ${ }^{3}$

Any large series of investigations on teeth will inevitably be gathered from individuals of a lower social rank than Anne Mowbray, but it is far from certain how much the diet of the nobility differed during the Tudor period from that of the ordinary well-to-do middle classes or even common artisans. Refined white flour still lay in the future, but sugar became increasingly common in the fifteenth century and honey had long been known. On balance it is likely that sugar was eaten sparingly at all levels of society before the seventeenth century, but the combined evidence of mediaeval history and mediaeval burial grounds falls well short of explaining this increase in dental decay-which gained rapid momentum after the close of the Saxon epoch.

Anne Mowbray as a late Plantagenet, as a child, and as a member of the nobility occupies a narrowly isolated and atypical position in British dental history. Let us hope that the interest of her case will stimulate the search for much more comparative material of this kind.

\section{Duodenal Inflammation}

Since 1837, when it was first described, ${ }^{1}$ the diagnosis of chronic duodenitis has been made with varying degrees of frequency and confidence, but nowadays most authorities are doubtful whether it merits recognition as a separate clinical and pathological entity. ${ }^{23}$ By definition chronic duodenitis is characterized clinically by symptoms closely similar if not identical to those of duodenal ulcer, and radiologically by a spastic irritable duodenal cap which displays a coarse irregular or reticular pattern of mucosa but in which no ulcer crater is demonstrable. In a recent study ${ }^{4}$ a group of patients having these features were further investigated by means of augmented histamine tests and biopsy of the duodenal mucosa. The findings were contrasted with those obtained from three other groups of persons comprising normal people, patients with "functional" dyspepsia, and patients with duodenal ulcer respectively. In the group with duodenitis, the chronic inflammatory changes noted histologically in the duodenal mucosa resembled those observed in cases of duodenal ulcer, but output of gastric acid was within the normal range.

\footnotetext{
${ }^{1}$ Baudin, J. B., M.D. thesis, Paris, 1837, quoted by Ostrow, J. D., and Resnick, R. H., Ann. intern. Med., 1959, 51, 1303.

${ }^{2}$ Bockus, H. L., Gastroenterology, 2nd ed., Vol. 1. Philadelphia. 1963.

${ }^{3}$ Hawkins, C. F., Diseases of the Alimentary Tract. London. 1963.

' Beck, I. T., Kahn, D. S., Lacerte, M., Solymar, J., Callegarini, U. Geokas, M. C., and Phelps, E., Gut, $1965,6,376$

${ }^{5}$ Wormsley, K. G., and Grossman, M. I., ibid., 1965, 6, 427.

${ }^{6}$ Doniach, I., and Shiner, M., Gastroenterology, 1957, 33, 71 .

7 Williams, A. W., Edwards, F., Lewis, T. H. C., and Coghill, N. F. Brit. med. F., 1957, 1, 372 .

${ }^{8}$ Fraser, G. M., Pitman, R. G., Lawrie, J. H., Smith, G. M. R., Forrest, A. P. M., and Rhodes, J., Lancet, 1964, 2, 979.

- Whitby, J., Brit. med. F., 1958, 2, 313.

${ }^{10}$ Ostrow, J. D., and Resnick, R. H., Ann. intern. Med., 1959, 51, 1303.
} 